\title{
Trade Openness And Inflation: Panel Data Evidence For The Caribbean
}

\author{
Chrystol Thomas, Central Bank of Barbados, Barbados
}

\begin{abstract}
High rates of inflation are a recurrent problem in Caribbean countries. Statistics show that small open developing economies, like those in the Caribbean, are relatively open when compared to more developed countries. Romer (1993) noted that global developments negatively influence inflation thus causing a negative link with trade openness. This paper re-examined this relationship for 8 Caribbean countries over a 30-year period. The validity of Romer's (1993) main result is investigated using a modern panel data approach. The results showed that openness positively influences inflation and validated the notion that the Caribbean countries are vulnerable to external shocks.
\end{abstract}

Keywords: Inflation; Trade openness; Panel Data

\section{INTRODUCTION}

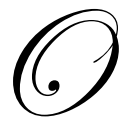

ne major macroeconomic challenge facing countries is the ability to sustain desirable price levels. Inflation has always been a concern for policymakers as it fosters much economic uncertainty, which may hinder economic growth. Therefore, many countries have sought to achieve price stability, as large changes in price levels cause countries to undergo democratic instability, fiscal austerity and structural reform (Dornbusch 1992). In the 1990s, inflation-targeting policies have been popular particularly in small countries that were highly open to international trade. Consequently, there has been a substantial decline in inflation rates around the world for both developed and developing countries (Bowdler and Malik 2006). Besides inflation-targeting, other factors have been identified to have contributed to the decline of inflation worldwide. These included better monetary policy, the attendant acceleration of productivity, and the increased level of competition in both product and labour markets that resulted from the interplay of increased globalization (Rogoff 2003; and Wynne and Kersting 2007).

Recently, in 2008, there has been a spike in international prices for food and oil commodities. Recent data from FAO noted that the slowdown in productivity growth was partially responsible for such increases. Additionally, the accelerating demand from emerging economies like China has placed added pressure on world prices. It has also been argued that the global economic crisis, which began in late 2007, has further compounded the situation (Holmes et al. 2009). The Caribbean countries, which are characterised as small, open and developing, have been affected by these international shocks as there have been adverse impacts on their economies. One of the macro-economic issues facing the region is the upward movement in general prices.

This paper investigates the impact of the degree of trade openness on inflation for a total of 8 Caribbean countries for the period 1980 to 2009. The work departs from previous research in that we move beyond crosssectional correlations and utilize temporal variation in the data by using the modern panel data techniques that controls for individual heterogeneity and misspecification. The empirical results suggested a positive relationship between openness and inflation, which provides contrary findings to the seminal paper by Romer (1993). These results are also observed in various subsamples when the time-series dimensions of the panel are changed. Moreover, the study concludes that the relationship between inflation and openness are neither restrict to any group of countries nor to a specific time period. Thus, there are countries that may increase their levels of openness and experience a reduction in the levels of inflation. 
The remainder of this paper is organized as follows. Section 2 gives a brief note on the historical trends for inflation and openness. Section 3 highlights some of the theoretical and empirical literature on inflation. Section 4 sets out our methodology and data while we present our empirical findings in section 5. Section 6 concludes the paper and provides some possible policy implications.

\section{GENERAL TRENDS IN INFLATION AND OPENNESS}

\section{Inflation}

Figure 1 shows the inflation rates for selected Caribbean countries over the period 1980 to 2009. It can be seen that high rates of inflation have been a recurrent problem in the Caribbean. For the sampled Caribbean countries, inflation rates averaged about 4.3 percent between 1980 and 2009. This rate is just above the accepted target rate, of between 1 and 3 percent, for most developed countries. ${ }^{1}$

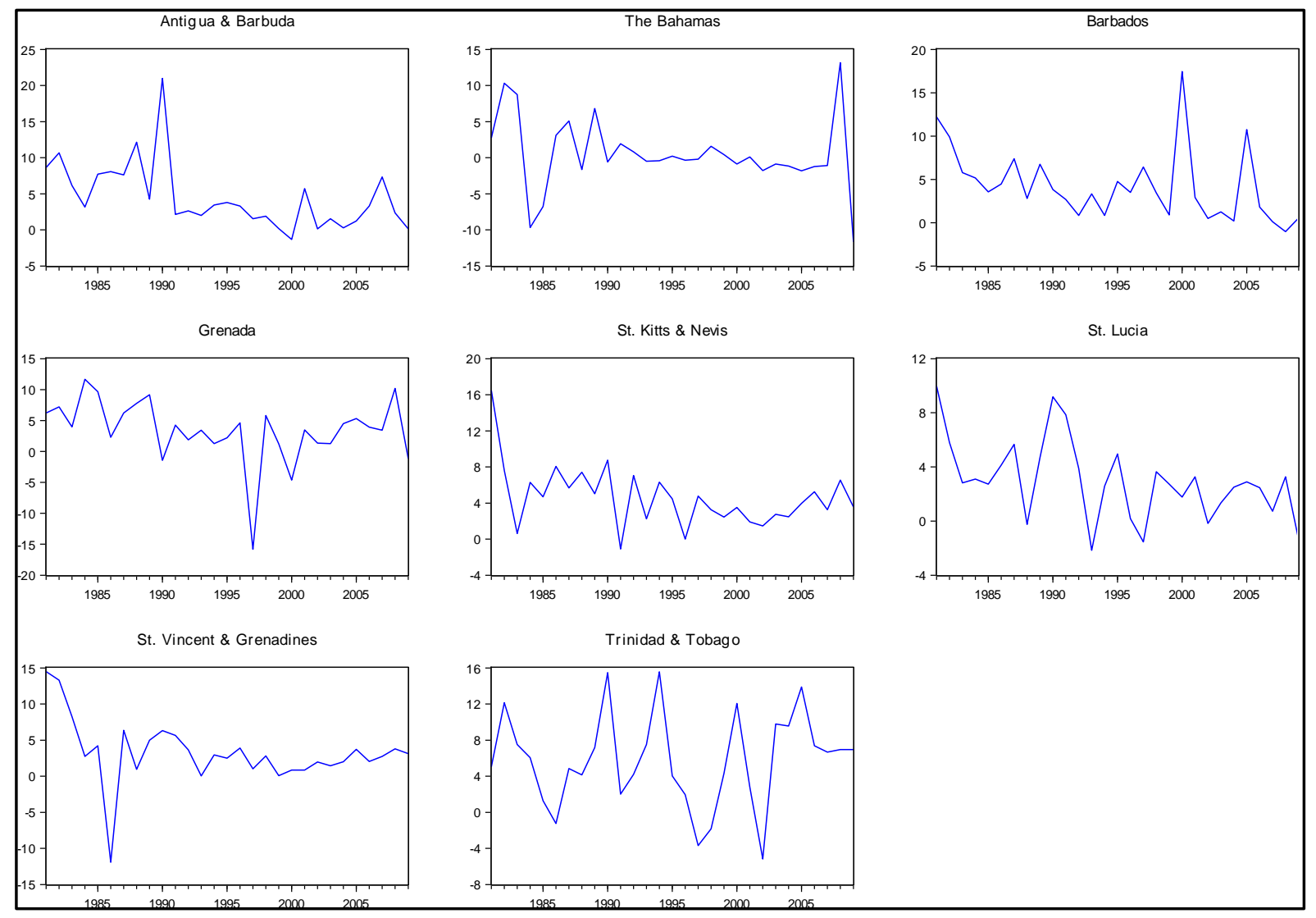

Figure 1: Inflation in Selected Caribbean Countries

During the 1980s, inflation was in the region of about 5.6 percent, which was mainly due to the oil price shock in the late 1970s and early 1980s. By the 1990s, there was a fall in the general trend in prices as the mean level of inflation declined substantially for all 8 countries, resulting in an overall average inflation level of 2.9 percent. This decline reflects the world-wide attempt of inflation-targeting. In the earlier part of the twenty-first century, there have been relatively low rates of price changes. However, by 2005, inflation rates accelerated due to hikes in fuel and food prices. This upward trend continued into the later years of the decade (2000 to 2009) on

\footnotetext{
${ }^{1}$ Some of the developed countries include Canada, New Zealand, and the United Kingdom.
} 
account of high aggregate demand from emerging markets, lower productivity from adverse weather conditions and the U.S financial crisis that began in 2007. Trinidad and Tobago, for example, experienced double digits inflation levels.

\section{Openness}

The degree of openness, as measured by the ratio of external trade of goods and services to GDP, is illustrated in Figure 2 for the 8 Caribbean countries. The graphs show a downward trend for most of the countries over the three decades. In the 1980s, openness in the region was on average $133 \%$ of GDP while the twenty-first century recorded $113 \%$ of GDP. This was attributable to increased competitiveness in international markets due to globalisation and the global recession, which was triggered by a spike in the price of oil. As such, the growth in exports and imports for the countries fell except for the case of Trinidad and Tobago who benefitted from a more industrialised economy. In general, the descriptive statistic reported that openness over the full period was about $122 \%$ of GDP. These levels of openness are quite high when compared to more developed economies such as the United States. The comparable ranges for the United States were 20 to 28\% of GDP. This comparison suggests that there is a high level of dependency on the international market by the Caribbean countries, especially as it relates to imports of goods.

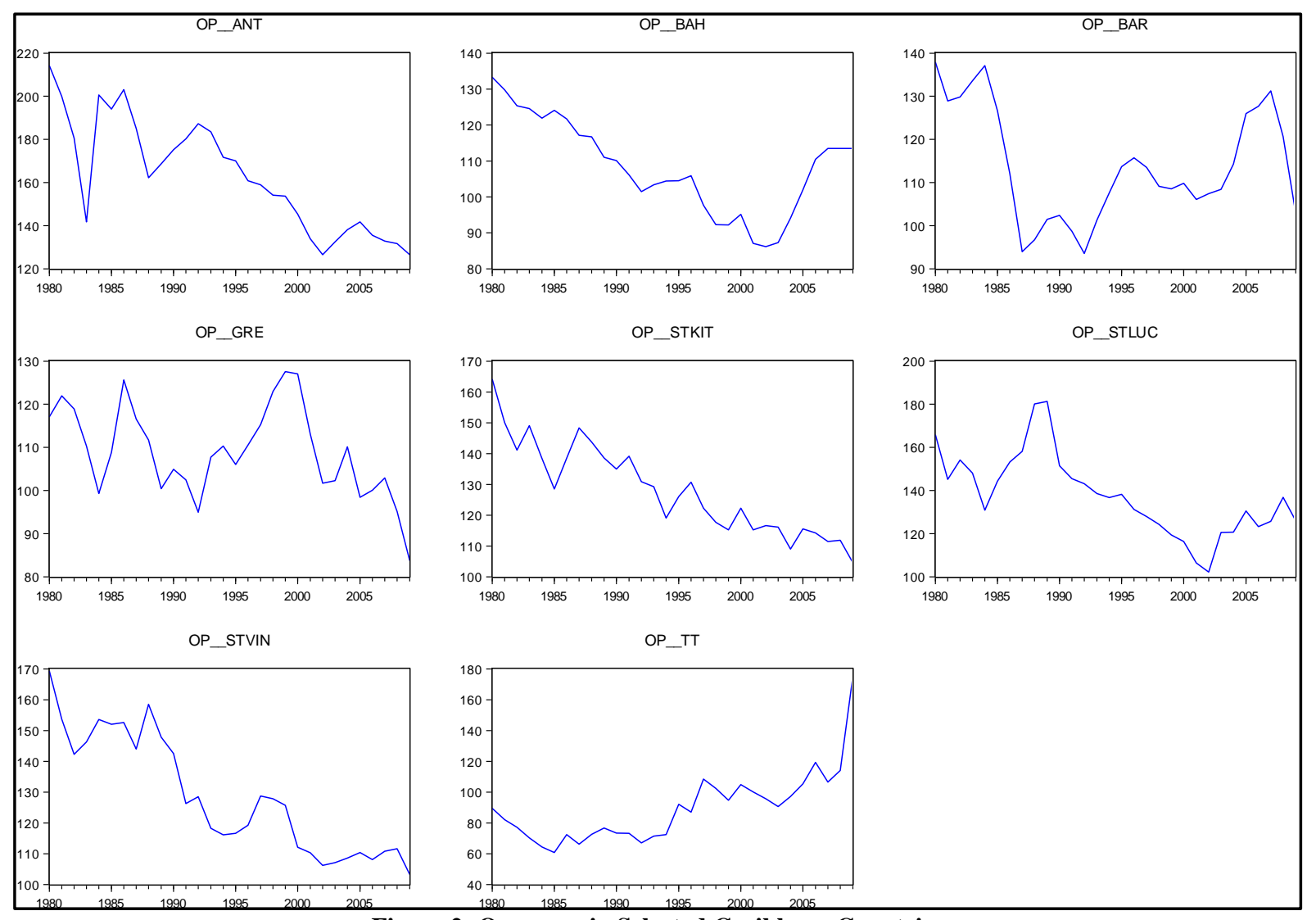

Figure 2: Openness in Selected Caribbean Countries

\section{LITERATURE REVIEW}

For many decades, price levels have been a core area of research for many researchers who sought to explain the factors responsible for its movements. Different schools of thought have provided significant contributions to what they believe are responsible for causing inflationary pressures. Monetarists argued that 
inflation is mainly influenced by how fast the money supply grows or falls thus being a monetary phenomenon. On the other hand, Keynesian economic theory identified demand push and cost pull factors as the main reasons for inflation. Generally, some economists agree that the growth in money supply have greater influence in the long-run while supply and demand pressures tend to affect short to medium term inflation levels.

In the age of globalisation, countries became more open to trade and economists have linked such changing patterns to inflation levels. Empirically, Romer (1993) provided a seminal paper that found a negative relationship between trade openness and inflation for a cross-section of 114 countries over the period 1973 to 1988. According to Romer, the theory behind models of this nature is based on unanticipated monetary expansion leading to real currency devaluation. He noted that openness reduces the impact of surprise monetary expansion on the real value of the currency. If an economy with a low degree of openness expands domestic output relative to foreign output, it is assumed that the relative price of domestic goods will fall thus increasing export levels, foreign reserves and hence inflation. Therefore, Romer predicted that policy makers' incentives to increase local production in an open economy will lead to lower levels of equilibrium inflation under discretionary policy.

Since Romer's influential work, numerous authors have found similar relation between inflation and openness. Terra's (1998) study for 114 countries found a strong negative relation among severely indebted countries during the debt crisis period in the 1980s. Badinger (2009), Wynne and Kersting (2007), Boschen and Weise (2003), Bowdler and Malik (2005), Muhammad and Batool (2006), Daniels and VanHoose (2006) and Alfaro (2005) also found negative correlations between trade openness and inflation.

Recently, Nasser et al. (2009) re-examined the evidence linking trade openness and inflation for 152 countries during the period 1950-1992 using a panel data methodology. Their empirical results supported Romer's (1993) argument and were robust for different specifications and time periods. The authors' findings also rejected Terra's (1998) criticism that the negative relationship between openness and inflation is due to severely indebted countries in the debt crisis period. Their paper suggested that models with the absence of a pre-commitment in monetary policy, leads to inefficiently high inflation, which is an important prediction that more open economies should have lower inflation rates. Lin (2010) also employed panel data techniques for 106 countries from 1970 to 2007. Lin found that there is an indirect effect of trade openness on inflation when inflation is higher but no effect when inflation is lower. The evidence was robust when controlled for exchange rate regime and for indebted countries.

The negative relationship between openness and inflation, proposed by Romer's (1993) paper, has been challenged by Temple (2002), Bleaney (1999) and Kim and Beladi (2005). Temple (2002) empirically tested this correlation by formulating a link between trade openness and the Phillips curve. Temple found that the basis on which the slope of the Phillips curve is associated with openness is based on small open economy models with nominal rigidity. His findings further showed that there is little support of a correlation between openness and the output-inflation trade-off. Bleaney (1999) noted that the negative relationship between openness and inflation is weak as the link disappeared in the 1990s. Kim and Beladi (2005) examined 62 countries and found varying correlations for different types of economies. Their results showed positive and significant relation between price level and openness for some advanced economies like the U.S., Belgium and Ireland while there was mainly a negative relationship for developing countries. Wu and Lin (2006) also found different relations for developed and lesser developed countries.

On reviewing some of the empirical studies on the linkages between trade openness and inflation, evidence suggests that there was generally a negative correlation between the two variables. The literature also revealed some important considerations for the relation between the levels of openness and inflation. One can infer that the correlation between openness and inflation is mainly robust for different time periods. Also, previous studies on this issue are normally cross-section analyses, in which panel data techniques were adopted to verify the relation between inflation and openness. 


\section{DATA AND METHODOLOGY}

\subsection{Data}

To examine the impact of trade openness on inflation, we use annual data for 8 Caribbean countries: Antigua and Barbuda (ANT), The Bahamas (BAH), Barbados (BAR), Grenada (GRE), St. Kitts and Nevis (STKIT), St. Lucia (STLUC), St. Vincent and the Grenadines (STVIN), and Trinidad and Tobago (TT). Like Kim and Beladi (2005), the natural logarithm of the GDP deflator was used as a proxy for inflation while openness was calculated by summing exports and imports of goods and services and expressing it as a percentage of GDP. As discussed in section 3 , the relation between openness and inflation is mixed.

To determine this relationship, other variables were also considered as analysing the effect of openness on inflation in a vacuum gives an incomplete picture of the changes in price levels. Therefore, based on the factors highlighted in Bynoe et al. (2007) for Latin America and the Caribbean, we employed the fiscal balance (FB), per capita income (Ypc), average crude price of petroleum (OIL), and a dummy for general elections (ELEC).

The a priori for the fiscal balance should be positive with inflation since the data comprised mainly of deficits, which is financed through money creation. Domac and Yucel (2005) and Catao and Terrones (2001) found evidence to support this relationship. We also expect an increase in per capita income to create higher price levels, as the demand for goods and services rises, which may trigger demand pull inflation. The impact of oil price shocks on inflation in inconclusive. However, given that most of the countries in our sample are net importers, we anticipate that when oil prices rise, domestic prices will also increase as oil is an input in almost all productive sectors. Political factors, such as elections, have been noted to have a direct relation with price movements. The political business cycle models of Nordhaus (1975) and Lindbeck (1976) indicated that central banks normally create expansionary monetary policy during election periods in order to boost the chances of re-election for the governing party.

All data were converted to one currency and expressed in millions of United States dollar. The nominal variables were expressed in logarithm form with the exception of fiscal balance. We use logarithm to remove the presence of a number of very high data points in the sample. The data for export of goods and services, import of goods and services, gross domestic product (GDP) were obtained from the World Bank, while GDP deflator, exchange rate, population and the petroleum average crude price were taken from the IMF's International Financial Statistics dataset. Data for fiscal balance was acquired from the various central banks. The dataset for each country is for the period 1980 to 2009 , a total of 30 observations.

\subsection{Methodology}

There has been much emphasis on analysing the properties of time series before establishing any relationship between variables. The study used recent developments in panel unit root and co-integration analyses. Three major unit root tests were employed: the Levin, Lin and Chu (2002), which has a common unit root process as the null hypothesis; the Im, Pesaran and Shin (2003), and the Augmented Dickey Fuller Fisher chi-square (Dickey and Fuller, 1979), which both have individual unit root processes as the null hypothesis. In the event of nonstationary variables in level, two test statistics for the existence of co-integrating relationships among the variables are employed. The Pedroni $(1999,2000)$ panel co-integration test develops several within and between dimensions and has no co-integration as its null hypothesis. The Kao (1999) co-integration test also has a null hypothesis of no co-integration. As shown in Table 2, both techniques indicated the presence of at least one co-integrating equation among the variables.

To ensure consistency, we adopted a model similar to Romer (1993). We estimated the long run relationship between openness and inflation using the dynamic ordinary least square (DOLS) method proposed by Kao and Chiang (2000). This technique includes lags and leads in each equation for the first difference of the I(1) variables to correct for possible autocorrelation and endogeneity. Two lags and leads were employed as annual data are used. Therefore, the following model was regressed: 
$L I N F_{i t}=\alpha_{i t}+\beta_{i} x_{i t}^{\prime}+\sum_{j=-h}^{h} \gamma_{i j}^{\prime} \Delta x_{i t-j}^{I}+\mu_{i t}$

where $x_{i t}^{\prime}=(L O P, L O I L, L Y p c, F B)$ with $i=1, \ldots . \mathrm{N}$ countries over $t=1, \ldots \mathrm{T}$ time periods. The subset of $\mathrm{I}(1)$ variables of $x$ is denoted by $x^{I}, \beta$ is the vector of long run slope coefficients and $\Delta x_{t+j}^{I}$ accounts for the possible endogeneity of $x$. The composite error term is expressed by $\mu_{i t}$, which includes individual effects, time effects and normally distributed error term with mean zero and variance $\sigma_{u}^{2}$. A dummy control variable for general elections is also considered when estimating the equation.

A general-to-specific reduction process was applied where only significant variables were retained. To account for country heterogeneity, the model was estimated with fixed effects using cross-section weights. White cross-section is included in the estimation to account for cross-equation correlation. The model was also tested for robustness by utilising various model specification and time periods. The results from these models are presented in Table 3.

\section{RESULTS}

The results from Tables 1 and 2 suggested that all the variables are integrated to the order 1 and that there is the presence of at least one co-integrating vector.

Table 1: Unit Root Tests

\begin{tabular}{|c|c|c|c|c|c|}
\hline \multirow{2}{*}{ Variable } & & \multicolumn{2}{|c|}{ Individual Root } & \multirow{2}{*}{$\begin{array}{c}\text { Common Root } \\
\text { LLC }\end{array}$} & \multirow{2}{*}{ Decision } \\
\hline & & IPS & Fisher-ADF $^{ \pm}$ & & \\
\hline \multirow{2}{*}{ FB } & Level & -0.3 & -0.4 & 1.4 & \multirow{2}{*}{$\mathbf{I}(\mathbf{1})$} \\
\hline & 1st Difference & $-7.7 * * *$ & $-7.2 * * *$ & $-2.6 * * *$ & \\
\hline \multirow{2}{*}{ LINF } & Level & -0.88 & -0.86 & $-1.6^{*}$ & \multirow{2}{*}{$\mathbf{I}(\mathbf{1})$} \\
\hline & 1st Difference & $-6.6 * * *$ & $-6.0 * * *$ & $-6.4 * * *$ & \\
\hline \multirow{2}{*}{ LOIL } & Level & 2.65 & 2.8 & 1.13 & \multirow{2}{*}{$\mathbf{I}(\mathbf{1})$} \\
\hline & 1st Difference & $--6.6^{* * *}$ & $-6.5 * * *$ & $-10.4 * * *$ & \\
\hline \multirow{2}{*}{ LOP } & Level & 0.43 & $-1.5^{*}$ & -0.9 & \multirow{2}{*}{$\mathbf{I}(\mathbf{1})$} \\
\hline & 1st Difference & $-7.6 * * *$ & $-5.5 * * *$ & $-5.3 * * *$ & \\
\hline \multirow{2}{*}{ LYPC } & Level & -0.25 & 1.58 & 5.53 & \multirow{2}{*}{$\mathbf{I}(\mathbf{1})$} \\
\hline & 1st Difference & $-2.5 * * *$ & $-2.48 * * *$ & $-4.3 * * *$ & \\
\hline
\end{tabular}

Notes:

1. $*, * *, * * *$ indicates a rejection of the null hypothesis at the $10 \%, 5 \%$ and $1 \%$ levels of significance, respectively.

2. ${ }^{ \pm}$test shows the ADF-Choi z-statistic

Table 2: Co-integration Tests Results

\begin{tabular}{|c|c|c|c|c|c|c|}
\hline \multicolumn{7}{|c|}{ Pedroni Panel Co-integration Test } \\
\hline \multirow[t]{2}{*}{ Statistics } & \multicolumn{3}{|c|}{ Within Dimension (Panel Stat.) } & \multicolumn{3}{|c|}{ Between Dimension (Group Stat.) } \\
\hline & $\begin{array}{c}\text { No intercept } \\
\text { No Trend }\end{array}$ & $\begin{array}{l}\text { Intercept } \\
\text { No Trend }\end{array}$ & $\begin{array}{c}\text { Intercept } \\
\text { Trend }\end{array}$ & $\begin{array}{l}\text { No intercept } \\
\text { No Trend } \\
\end{array}$ & $\begin{array}{l}\text { Intercept } \\
\text { No Trend }\end{array}$ & $\begin{array}{c}\text { Intercept } \\
\text { Trend }\end{array}$ \\
\hline $\mathrm{PP}$ & $-2.33 * *$ & $-1.92 * *$ & $-1.63 * *$ & $-2.85 * * *$ & $-2.22 * * *$ & $-1.82 * *$ \\
\hline $\mathrm{ADF}$ & $-2.14 * *$ & $-1.42 * *$ & $-1.66 * *$ & $-3.39 * * *$ & $-1.62 * *$ & $-1.53 * *$ \\
\hline \multicolumn{7}{|c|}{ Kao Residual Co-integration Test } \\
\hline $\mathrm{ADF}=-4.44 * *$ & & & & & & \\
\hline
\end{tabular}

Note:

1. $* * *, * * *$ indicates a rejection of the null hypothesis at the $10 \%, 5 \%$ and $1 \%$ levels of significance, respectively. 
Given that the variables entering the regression equation are co-integrated, we estimate the long-run equilibrium relationship between trade openness and inflation. To test the hypothesis formulated by Romer (1993), we have estimated several equations using different time specifications. The reason for this procedure is to check the robustness of the relationships.

As shown in Tables 3, the results indicated a direct relationship between openness and inflation. This positive link between trade openness and inflation wae extremely robust as the findings held for various restrictions in the time period. ${ }^{2}$ For the full sample a $1 \%$ change in openness is expected to bring about a reduction in inflation by $0.17 \%$. The magnitude of this relationship was higher for the 1980-1999 sample period but lower for the 19902009 period.

This result conflicts with that of Romer (1993) as well as Kim and Beladi (2005) who reported that developing countries were more prone to display a negative relationship. However, the positive correlation is not surprising as the data showed a general decline in the openness and inflation level of Caribbean countries over the last 20 years. Moreover, the Caribbean economies are said to be vulnerable to external shocks (Commonwealth Secretariat 2007). This is explained by the fact that these economies are price takers, have very little natural resources, rely mainly on the tourism sector for foreign exchange and are net importers. Therefore, any shock that affects the main trading partners of these economies (the U.S., and the U.K.) threatens the stability of the macroeconomy.

As anticipated, the study found significant and positive relationships between inflation and income for all sample periods. A rise in per capita income by US $\$ 1$ million will cause prices to augment by between $0.4 \%$ to about $0.5 \%$. This positive relationship also existed for government's fiscal balance, but with a smaller influence. These results provide evidence of possible demand-pull inflation in the long-run. In the case of the fiscal factor, it may also provide support for Monetarist's theory of money supply influencing inflation in the long-run since money is created to cover the deficit between government's revenue and expenditure.

Surprisingly, the variable for oil prices was found to be statistically insignificant for the full sample but was important in explaining inflation during the 1980 to 1999 period. This finding is possible as there was an oil price shock in the early 1980s, which can be seen from the price volatility in Figure 1. A one unit increase for the oil price shock resulted in general prices growing by approximately $0.2 \%$. Though the relationships are positive, the estimations suggested that the dummy variable for general elections was insignificant in determining inflation levels. This dispels the political business cycle models of Nordhaus (1975) and Lindbeck (1976). One possible explanation is that one monetary authority represents 6 of the sampled countries thus making it difficult for government to sway monetary policy decisions.

\footnotetext{
${ }^{2}$ The results were consistent when sample size was restricted to 10 -year periods (1980-1989; 1990-1999; 2000-2009) and 20year periods (1980-1999; 1990-2009).
} 
Table 3: Regression Results*

\begin{tabular}{|c|c|c|c|c|c|c|c|c|c|}
\hline \multicolumn{10}{|c|}{ Dependent Variable: LINF } \\
\hline \multirow{2}{*}{ Variables } & \multicolumn{3}{|c|}{$\begin{array}{l}\text { Full Sample: } 1980-2009 \\
\end{array}$} & \multicolumn{3}{|c|}{ Restricted Sample: $1980-1999$} & \multicolumn{3}{|c|}{ Restricted Sample: 1990-2009 } \\
\hline & Coefficient & Std. error & Prob. & Coefficient & Std. error & Prob. & Coefficient & Std. error & Prob. \\
\hline $\mathrm{C}$ & & & & -1.403 & 0.428 & 0.001 & 0.560 & 0.314 & 0.077 \\
\hline LOP & 0.169 & 0.043 & 0.000 & 0.187 & 0.056 & 0.001 & 0.085 & 0.049 & 0.086 \\
\hline LYpc & 0.461 & 0.011 & 0.000 & 0.523 & 0.016 & 0.000 & 0.401 & 0.014 & 0.000 \\
\hline LOIL & & & & 0.150 & 0.024 & 0.000 & & & \\
\hline FB & 0.0004 & 0.0001 & 0.000 & 0.0009 & 0.00008 & 0.000 & 0.0001 & 0.000 & 0.006 \\
\hline Observations & 200 & & & 144 & & & 144 & & \\
\hline $\mathrm{R} 2$ & 0.93 & & & 0.96 & & & 0.92 & & \\
\hline Adjusted R2 & 0.92 & & & 0.95 & & & 0.91 & & \\
\hline S.E. of regression & 0.106 & & & 0.079 & & & 0.08 & & \\
\hline F-statistic & 150.9 & & & 189.2 & & & 109.0 & & \\
\hline Prob. (F-statistic) & 0.000 & & & 0.000 & & & 0.000 & & \\
\hline
\end{tabular}

Note:

* The findings for the leads and lags were not reported due to space limitations. The results can be obtained from the author. 


\section{CONCLUSION AND POLICY IMPLICATION}

This paper re-examined the evidence linking inflation and trade openness for 8 small open economies during the period 1980 to 2009. A panel data technique was employed to test the validity of the results obtained in Romer (1993) for the Caribbean. The findings were found to be robust as they persisted for various model specifications. The empirical results did not provide support for Romer's (1993), as there was a positive relationship between trade openness and inflation. The study also suggested that larger fiscal deficits and growth in per capita income result in higher inflation levels. Petroleum prices were found to influence inflation over the 1980 to 1999 period while the political factor, general elections, was insignificant.

Given that inflation is a recurring problem in the Caribbean, the monetary authorities should increase their cognizance on the extent of changes in the general price levels since there is little control over oil and commodity prices. The authorities should focus on other areas that may generate acceptable inflation levels. One factor that governments could concentrate on is ways on improving efficiency and productivity. This will ensure that the goods and services are provided at the lowest cost thus lowering the growth in price levels, especially in food.

With aggregate demand playing a significant role in determining inflation, Governments need to be more prudent in their fiscal management. They need to control public expenditure levels, which will reduce the high demand for some consumer goods and reduce the levels of money creation. The higher national income and rising wage levels also contribute to demand pull pressures on price levels. To control for these, there are various options that the monetary authority can adopt to help channel some of the demand credit into savings that can be used internationally, thus bringing in more foreign reserves for the economy. This is of particular importance since the economies under investigations have mainly pegged exchange rates with the United States.

The results presented in this paper validated the notion that developing countries, such as those in the Caribbean region, are vulnerable to external shocks as petroleum prices are found to positively influence local prices. Vulnerabilities, like these, can place constraints on the ability of nations to grow, therefore it is important to decrease such dependence and support initiatives such as renewable energy and technological advancements.

Ultimately, there is further room for future research on inflation as economies are ever-changing. Natural reserve levels have not been explicitly explored as a determinant of inflation. To this aim, supply factors need to be given closer consideration in assessing the changes in price levels.

\section{AUTHOR INFORMATION}

Ms. Chrystol Thomas is an Economist at the Central Bank of Barbados, working in the Public and Debt Management Unit. She also lectures at the University of the West Indies, Cave Hill campus and is a member of the Barbados Economic Society. Her research interests are fiscal and debt sustainability, international macroeconomics, monetary economics, energy economics and health economics. E-mail: chrystol.thomas@centralbank.org.bb

\section{REFERENCES}

1. Alfaro, Laura. 2005. Inflation, openness, and exchange-rate regimes. The quest for short-term commitment. Journal of Development Economics 77:229-249.

2. Badinger, Harald. 2009. Globalisation, the output-inflation tradeoff and inflation. European Economic Review 53:888-907.

3. Bleaney, M. 1999. The Disappearing Openness-Inflation Relationship: A Cross-Country Analysis of Inflation Rates, IMF Working Paper WP/99/161 (December).

4. Boschen, John and Charles Weise. 2003. What Starts Inflation: Evidence from the OECD countries. Journal of Money Credit and Banking 35:324-49.

5. Bowdler, Christopher and Adeel Malik. 2006. Openness and Inflation Volatility: Cross-country evidence. Journal of Economic Literature.

6. Bynoe, Denny, Winston Moore and Natalia Morgan. 2007. Inflation starts in Latin America and the Caribbean. Central Bank of Barbados Working Paper. 
7. Catao, L. and M. Terrones. 2001. Fiscal deficits and inflation: A new look at the emerging market evidence. IMF Working Paper, NO: WP/01/74.

8. Commonwealth Secretariat, 2007. Small States: Economic Review and Basic Statistics. Annual Series: Vol.12.

9. Daniels, Joseph and David Van Hoose. 2006. Openness, the sacrifice ratio and inflation: Is there a puzzle? Journal of International Money and Finance 25:1336-47.

10. Domac, I. And M. Yucel. 2005. What triggers inflation in emerging market economies. Review of World Economics 141(1):141-64.

11. Dornbusch, Rudiger. 1992. The case of trade liberalisation in developing countries. The Journal of Economic Perspectives 6(1):69-85.

12. Holmes, Rebecca, Nicola Jones and Hannah Marsden. 2009. Gender vulnerabilities, food price shocks and social protection responses. ODI Background Notes. http://www.odi.org.uk

13. Im, K.S., M.H. Pesaran and Y. Shin. 2003. Testing for unit roots in heterogeneous panels. Journal of Econometrics 115:53-74.

14. Kao, C., Chiang, M., 2000. On the estimation and inference of a cointegrated regression in panel data. Advances in Econometrics 15, 179-222.

15. Kim, M., and H. Beladi. 2005. Is free trade deflationary? Economics Letters, 89:343-349.

16. Levin, A., C. Lin, and C. Chu. 2002. Unit root tests in panel data: asymptotic and finite-sample properties. Journal of Econometrics 108:1-24.

17. Lin, Hsin-Yi. 2010. Openness and Inflation Revisited. International Research Journal of Finance and Economics 37:40-5.

18. Lindbeck, A. 1976. Stabilisation policies in open economies with endogenous politicians. American Economic Review Papers and Proceedings 66:1-19.

19. Mark, N., Sul, D., 2003. Cointegration Vector Estimation by Panel DOLS and Long-run money Demand. Oxford Bulletin of Economics and Statistics 65(5), 655-80.

20. Muhammad, Hanif and Irem Batool. 2006. Openness and Inflation: A case study of Pakistan. MPRA Paper 10214. http://mpra.ub.uni-muenchen.de/10214/

21. Nasser, Omar, Adolfo Sachsida and Mario Jorge Cardoso de Mendonca. 2009. The openness-inflation puzzle: Panel data evidence. International Research Journal of Finance and Economics 28:169-81.

22. Nordhaus, W. 1975. The political business cycle. Review of Economic Studies 42:169-90.

23. Rogoff, Kenneth. 2003. Globalisation and global disinflation. Presented at the Federal Reserve Bank of Kansas City conference. August 28-30.

24. Romer, David. 1993. Openness and inflation: Theory and evidence. The Quarterly Journal of Economics 108(4):869-903.

25. Temple, Jonathan. 2002. Openness, inflation and the Phillips curve: A puzzle. Journal of Money, Credit and Banking 34:450-68.

26. Terra, Maria. 1998. Openness and Inflation: A New Assessment. The Quarterly Journal of Economics 11(2):641-48.

27. Wu, Chung-Shu and Jin-Lung Lin. 2006. The relationship between openness and inflation in the NIE's and G7. Journal of Economic Literature.

28. Wynne, Mark. And Erasmus Kersting. 2007. Openness and Inflation. Staff Papers of the Federal Reserve Bank of Dallas No.2.

29. Zellner, Arnold. 1962. An efficient method of estimating seemingly unrelated regression equations and tests for aggregation bias. Journal of the American Statistical Association 57:348-368. 